Acta vet. scand. $1972,13,206-217$.

From the National Veterinary Institute, Stockholm

and the Research and Development Laboratories, Astra Läkemedel AB, Södertälje, Sweden.

\title{
STUDIES ON SUDDEN FATALITIES AMONG PIGLETS FOLLOWING PARENTERAL IRON THERAPY
}

\author{
By \\ S. Lindvall, Gunilla Moberg and B. Nordblom
}

\begin{abstract}
LINDVALL, S., GUNILLA MOBERG and B. NORDBLOM: Studies on sudden fatalities among piglets following parenteral iron therapy. Acta vet. scand. $1972,13,206-217$. - An investigation was carried out in order to clarify whether there is a correlation between the latent iron-binding capacity, UIBC, in the serum of suckling piglets and sudden fatalities occurring among these animals when they are treated with $250 \mathrm{mg}$ trivalent iron in the form of a complex also containing dextrin, sorbitol, citric acid and lactic acid.

In all, 97 animals from 9 litters were used. By administering 100 mg oral divalent iron to 22 animals, the iron-binding capacity was saturated or appreciably reduced $3 \mathrm{hrs}$. after the oral treatment. After this time, the animals were treated with parenteral iron. Seventeen other animals were treated with $100 \mathrm{mg}$ divalent iron and immediately afterwards with parenteral iron. Three hrs. later, the ironbinding capacity of the animals was exceeded. In 32 of the control animals, UIBC was high before the parenteral treatment. No fatalities were observed among the animals treated with parenteral iron.

Twenty-three of the animals had a high iron-binding capacity in spite of having diarrhoea. On parenteral treatment of these animals with the iron complex, no fatalities were observed which could be ascribed to the treatment.

The mechanism for the sudden fatalities among suckling piglets after parenteral administration of iron is discussed.
\end{abstract}

parenteral iron; or a l iron; piglet; sudden fat alities; intestinal infections; serum iron; unsaturated iron-binding capacity; total ir on-binding capacity.

It has been reported by Nilsson (1960), Henriksson (1962), Ueberschär (1966), Köhler (1966) and Behrens (1969) that fatalities have occurred in certain litters of piglets within $24 \mathrm{hrs}$. following treatment for anaemia by means of parenteral iron therapy. 
Treatment with oral iron can also lead to sudden fatalities in certain litters of piglets (Brag 1957). It was established that the dead animals manifested a waxy degeneration of the muscle, and assumed that the reason for this muscle degeneration was a deficiency of vitamin E. Lannek \& Tollerz (1962) have studied the role of vitamin $E$ in the sensitivity of the animals to parenteral iron therapy. These authors demonstrated an increase in mortality in those litters having a deficiency of this vitamin. However, they did not preclude the possibility that other reasons than vitamin $E$ deficiency could be responsible for the sudden fatalities.

The significance of vitamin $E$ in sudden fatalities among piglets was also discussed by Henriksson and Köhler. The latter author assumed that vitamin $\mathbf{E}$ deficiency is of great importance in this connection, but he nonetheless considers that the immediate causes are of a more complex nature.

In the dead piglets which were examined by Nilsson, serious myocardial degeneration was ascertained. However, the author considers that the cause of death was not established, but he suspects some latent disorder which was aggravated by the treatment.

The pathological anatomical investigation of the cases described by Ueberschär showed that the dead animals had extensive oedema and focal necroses and that there was bleeding at the sites of injection. Ueberschär considers that the tissue toxic properties of the iron preparation are the cause of these changes, which are certainly responsible for the death of the animals. On the other hand, Behrens considers that the nature and course of the illness suggest acute iron poisoning and that the localized changes are either not responsible for the fatalities or responsible only to a limited extent. He rather considers that the fatalities are the result of a specific toxicity of the iron preparation and a particular susceptibility of certain litters or piglets. Behrens also considers that a causal relationship may exist between the total iron-binding capacity of the animals and the fatalities.

As with other parenteral preparations fatalities have also been observed in certain litters on using a complex of iron, dextrin, sorbitol, citric acid and lactic acid (Iroject, Astra, Sweden) for preventing anaemia in piglets (Brag, personal communication). In order to determine whether there is a correlation between the latent iron-binding capacity in serum and fatalities 
among piglets treated with parenteral iron preparations, the latent iron-binding capacity was determined immediately before administration of the iron preparation. The experiments were carried out on suckling piglets on a farm where fatalities had been noted previously and on another farm where intestinal infections among the piglets had given rise to considerable problems. The latter farm was chosen because of the proposed correlation between iron injections, intestinal infection and fatalities. The iron-binding capacity of serum of piglets from litters from 2 other farms was saturated with iron and the animals were subsequently provoked by parenteral administration of the above-mentioned preparation.

\section{MATERIAL AND METHODS}

\section{Iron preparations}

The parenteral iron preparation has been described by Högberg et al. (1968). It contains $100 \mathrm{mg} \mathrm{Fe}^{3+}$ per $\mathrm{ml}$ in the form of a sterile solution of a complex or iron, dextrin, sorbitol, citric acid and lactic acid. In addition $0.3 \%$ phenol is added to the solutions as a preservative.

Oral iron was administered to the animals in the form of a geiatin capsule containing ferrous sulphate corresponding to $50 \mathrm{mg} \mathrm{Fe}{ }^{2+}$. This capsule is dissolved within $3 \mathrm{~min}$. by the gastric juice.

\section{Animals and doses}

In the experiments, 9 litters comprising a total of 97 animals were used. The litters were from 4 experimental farms of varying size and with different feeding routines and hygienic standard.

Litter 1 (farm A). This litter - 12 animals (Nos. 1-12) - was a farm where fatalities had been noted previously on treatment with the above-mentioned iron preparation. Blood samples were taken from the jugular vein for determination of serum iron (SI) and unsaturated iron-binding capacity (UIBC), when the piglets were 3 days old. Immediately afterwards $250 \mathrm{mg} \mathrm{Fe}{ }^{3+}$ was administered to all animals i.m. deep into the neck musculature (Table 1).

Litter 2 (farm B). Oral iron was administered to 7 out of 10 3-day old piglets (Nos. 13-22), the dose being $2 \times 50 \mathrm{mg} \mathrm{Fe} 2+$. Three hrs. later, blood samples were taken from all the animals for determination of SI and UIBC. Immediately afterwards 7 of the animals were given a deep i. m. injection of $250 \mathrm{mg} \mathrm{Fe}^{3+}$ (Table 2). 
Litter 3 (farm $C$ ). Three out of a litter of 10 5-day old piglets (Nos. 23-32) were treated with $2 \times 50 \mathrm{mg}$ oral $\mathrm{Fe}^{2+}$ and 3 with $2 \times 50$ $\mathrm{mg}$ oral $\mathrm{Fe}^{2+}+250 \mathrm{mg} \mathrm{Fe}{ }^{3+}$ i. $\mathrm{m}$. deep into the neck musculature. Three hrs. later, blood samples were taken from all the animals for determination of SI and UIBC, and immediately afterwards $250 \mathrm{mg}$ $\mathrm{Fe}^{3+}$ was administered i. $\mathrm{m}$. deep into the neck musculature to the 7 piglets which had not previously received parenteral iron (Table 3).

Litter 4 (farm $C$ ). Three out of a litter of 10 4-day old piglets (Nos. 33-42) were treated with $2 \times 50 \mathrm{mg}$ oral $\mathrm{Fe}^{2+}$ and 4 with $2 \times 50$ $\mathrm{mg}$ oral $\mathrm{Fe}^{2+}+250 \mathrm{mg} \mathrm{Fe}{ }^{3+}$ i. m. deep into the neck musculature. Subsequently, the same procedure was adopted as for litter 3. This litter had gastro-intestinal trouble in the form of diarrhoea (Table 4).

Litter 5 (farm $C$ ). Four out of a litter of 11 3-day old piglets (Nos. 43-53) were treated with $2 \times 50 \mathrm{mg}$ oral $\mathrm{Fe}^{2+}$ and 3 with $2 \times 50$ mg oral $\mathrm{Fe}^{2+}+250 \mathrm{mg} \mathrm{Fe}{ }^{3+}$ i. $\mathrm{m}$. deep into the neck musculature. Subsequently, the same procedure was adopted as for litter 3, except that SI and total iron-binding capacity (TIBC) were determined (Table 5).

Litter 6 (farm $C$ ). Four out of a litter of $113 \frac{1}{2}$-day old piglets (Nos. 54-64) were treated with $2 \times 50 \mathrm{mg}$ oral $\mathrm{Fe}^{2+}$ and 4 with $2 \times 50$ $\mathrm{mg}$ oral $\mathrm{Fe}^{2+}+250 \mathrm{mg}$ parenteral $\mathrm{Fe}^{3+}$. Subsequently, the same procedure was adopted as for litter 5 (Table 6).

Litter 7 (farm $C$ ). Four out of a litter of 10 3-day old piglets (Nos. 65-74) were treated with $2 \times 50 \mathrm{mg}$ oral $\mathrm{Fe}^{2+}$ and 3 with $2 \times 50$ $\mathrm{mg}$ oral $\mathrm{Fe}^{2+}+250 \mathrm{mg}$ parenteral $\mathrm{Fe}^{3+}$. Subsequently, the same procedure was adopted as for litter 5 (Table 7).

Litter 8 (farm D). This litter, which consists of 11 4-day old piglets (Nos. 75-85), is from a farm where there had been considerable problems with intestinal infections among the piglets. At the time of treatment, the animals had diarrhoea. A blood sample was taken for UIBC determination, and then $250 \mathrm{mg} \mathrm{Fe}{ }^{3+}$ was administered deep into the neck musculature (Table 8).

Litter 9 (farm $D$ ). This litter comprises 12 2-day old piglets (Nos. 86-97) and is from the same farm as litter 8. At the time of treatment, the animals had diarrhoea. Blood sampling and treatment was the same as for litter 8 (Table 9).

Post-mortem examinations and bacteriological tests were performed at the National Veterinary Institute from the 8 piglets which died during the experiments.

Serum iron (SI)

In litters $1-4$, serum iron was determined according to the method described by Lindvall $\&$ Andersson (1961). In litters 5 -7, the determination of serum iron was carried out using a Technicon autoanalyzer according to a method described by Giovanniello et al. (1967). 
Table 1. Sex, serum iron (SI), unsaturated iron-binding capacity (UIBC), total iron-binding capacity (TIBC) and complications of piglets 4 days of age from litter 1 .

\begin{tabular}{|c|c|c|c|c|c|}
\hline \multirow[b]{2}{*}{ Piglet no. } & \multirow[b]{2}{*}{ Sex } & \multicolumn{3}{|c|}{$\mu \mathrm{g} \mathrm{Fe} / 100 \mathrm{ml}$ serum } & \multirow[b]{2}{*}{ Complications } \\
\hline & & SI & UIBC & TIBC & \\
\hline 1 & ㅇ & - & 155 & - & none \\
\hline 2 & q & 188 & 115 & 303 & none \\
\hline 3 & q & 153 & 205 & 358 & none \\
\hline 4 & $q$ & 120 & 160 & 280 & none \\
\hline 5 & $\hat{\jmath}$ & 153 & 185 & 338 & none \\
\hline 6 & $\hat{o}$ & 205 & 140 & 345 & none \\
\hline 7 & 웅 & 158 & 195 & 353 & none \\
\hline 8 & ㅇ & 264 & 190 & 454 & none \\
\hline 9 & $\hat{o}$ & 188 & 200 & 388 & none \\
\hline 10 & q & 205 & 75 & 280 & none \\
\hline 11 & 우 & - & 215 & - & none \\
\hline 12 & $\hat{o}$ & 110 & 195 & 305 & none \\
\hline
\end{tabular}

Latent and total iron-binding capacity (UIBC and TIBC)

In litters $1-4,8$ and 9 , the latent iron-binding capacity was determined according to a method described by Cartwright $\&$ Wintrobe (1949) and TIBC obtained by addition of SI and UIBC, while in litters 5-7, the total iron-binding capacity was first determined in a Technicon autoanalyzer according to Giovanniello et al. and UIBC then obtained by subtraction of SI.

\section{RESULTS}

Correlation between saturation of UIBC and the sudden fatalities

On a farm where previous fatalities had occurred in connection with the administration of the iron preparation used in the experiments, the serum iron and iron-binding capacity in serum of the piglets of a new litter were investigated. Subsequently attempts were made to reproduce the previous fatalities by administering the same dose of the same batch of the preparation. It can be seen from the results given in Table 1 , that these 12 piglets had high serum iron values, but in spite of this a high unsaturated iron-binding capacity. No fatalities were noted in this experiment. 
T a b l e 2. Sex, treatment, serum iron (SI), unsaturated iron-binding capacity (UIBC), total iron-binding capacity (TIBC) and complications of piglets 3 days of age from litter 2.

\begin{tabular}{|c|c|c|c|c|c|c|c|c|}
\hline \multirow{3}{*}{ Piglet no. } & \multirow{3}{*}{ Sex } & \multicolumn{3}{|c|}{ Blood sample taken } & & & \multirow[b]{2}{*}{ serum } & \multirow{3}{*}{ Complications } \\
\hline & & \multirow{2}{*}{$\begin{array}{c}\text { after } \\
100 \mathrm{mg} \mathrm{Fe} \\
\text { orally }\end{array}$} & \multirow{2}{*}{$\begin{array}{c}\text { after } \\
100+200 \mathrm{mg} \mathrm{Fe} \\
\text { oral.+parent. }\end{array}$} & \multirow{2}{*}{$\begin{array}{c}\text { before } \\
250 \mathrm{mg} \mathrm{Fe} \\
\text { parenterally }\end{array}$} & \multicolumn{2}{|c|}{$\mu \mathrm{g} \mathrm{Fe} / 100 \mathrm{ml}$} & & \\
\hline & & & & & SI & UIBC & TIBC & \\
\hline 13 & q & - & - & $\mathbf{X}$ & 70 & 180 & 250 & none \\
\hline 14 & $\hat{\delta}$ & - & 一 & $\mathbf{X}$ & 122 & 228 & 350 & none \\
\hline 15 & 우인 & - & - & $\mathbf{X}$ & 40 & 108 & 148 & none \\
\hline 16 & ôे & $\mathbf{X}$ & - & 一 & 350 & 0 & 350 & none \\
\hline 17 & $\hat{o}$ & $\mathbf{X}$ & - & - & 484 & $\mathbf{0}$ & 484 & none \\
\hline 18 & 운 & $\mathbf{X}$ & - & - & 186 & $\mathbf{0}$ & 186 & none \\
\hline 19 & q & $\mathbf{X}$ & - & $\mathbf{X}$ & - & 0 & - & none \\
\hline 20 & $q$ & $\mathbf{X}$ & - & $\mathbf{X}$ & 458 & 25 & 483 & none \\
\hline 21 & $q$ & $\mathbf{X}$ & - & $\mathbf{X}$ & 330 & 0 & 330 & none \\
\hline 22 & 우 & $\mathbf{X}$ & - & $\mathbf{X}$ & 486 & $\mathbf{0}$ & 486 & none \\
\hline
\end{tabular}

T a ble 3. Sex, treatment, serum iron (SI), unsaturated iron-binding capacity (UIBC), total iron-binding capacity (TIBC) and complications of piglets 5 days of age from litter 3 .

\begin{tabular}{|c|c|c|c|c|c|c|c|c|}
\hline \multirow{3}{*}{ Piglet no. } & \multirow{3}{*}{ Sex } & \multicolumn{3}{|c|}{ Blood sample taken } & & & & \multirow{3}{*}{ Complications } \\
\hline & & \multirow{2}{*}{$\begin{array}{c}\text { after } \\
100 \mathrm{mg} \mathrm{Fe} \\
\text { orally }\end{array}$} & \multirow{2}{*}{$\begin{array}{c}\text { after } \\
100+250 \mathrm{mg} \mathrm{Fe} \\
\text { oral.+parent. }\end{array}$} & \multirow{2}{*}{$\begin{array}{c}\text { before } \\
250 \mathrm{mg} \mathrm{Fe} \\
\text { parenterally }\end{array}$} & \multicolumn{3}{|c|}{$\mu \mathrm{g} \mathrm{Fe} / 100 \mathrm{ml}$ serum } & \\
\hline & & & & & SI & UIBC & TIBC & \\
\hline 23 & 운 & - & - & $\mathbf{X}$ & 148 & 140 & 288 & none \\
\hline 24 & $q$ & - & - & X & 22 & 400 & 422 & none \\
\hline 25 & $\hat{o}$ & - & - & $\mathbf{X}$ & 72 & 268 & 340 & none \\
\hline 26 & $\hat{o}$ & - & - & $\mathbf{X}$ & 36 & 435 & 471 & none \\
\hline 27 & $q$ & - & $\mathbf{x}$ & - & 1440 & $\mathbf{0}$ & 1440 & none \\
\hline 28 & $\hat{o}$ & - & $\mathbf{X}$ & - & 915 & $\mathbf{0}$ & 915 & none \\
\hline 29 & $q$ & - & $\mathbf{X}$ & 一 & 1224 & 0 & 1224 & none \\
\hline 30 & $\hat{o}$ & $\mathbf{x}$ & - & $\mathbf{X}$ & 270 & 45 & $\mathbf{3 1 5}$ & none \\
\hline 31 & $q$ & $\mathbf{X}$ & - & $\mathbf{X}$ & 486 & $\mathbf{0}$ & 486 & none \\
\hline 32 & q & $\mathbf{X}$ & - & $\mathbf{X}$ & 405 & 0 & 405 & none \\
\hline
\end{tabular}

In order to saturate the latent iron-binding capacity before the parenteral administration, a very large dose of oral iron was given to 22 piglets in litters 2-7. Tables 2-7 show that this dose was so large that the latent iron-binding capacity was substantially reduced or completely saturated $3 \mathrm{hrs}$. after the oral administration, at which time the animals received parenteral iron without any fatal side-effect occurring. When the parenteral 
T a bl e 4. Sex, treatment, serum iron (SI), unsaturated iron-binding capacity (UIBC), total iron-binding capacity (TIBC) and complications of piglets 4 days of age from litter 4 .

\begin{tabular}{|c|c|c|c|c|c|c|c|c|}
\hline \multirow{3}{*}{ Piglet no. } & \multirow{3}{*}{ Sex } & \multicolumn{3}{|c|}{ Blood sample taken } & & & & \multirow{3}{*}{ Complications } \\
\hline & & \multirow{2}{*}{$\begin{array}{c}\text { after } \\
100 \mathrm{mg} \mathrm{Fe} \\
\text { orally }\end{array}$} & \multirow{2}{*}{$\begin{array}{c}\text { after } \\
100+250 \mathrm{mg} \mathrm{Fe} \\
\text { oral.+parent. }\end{array}$} & \multirow{2}{*}{$\begin{array}{c}\text { before } \\
250 \mathrm{mg} \mathrm{Fe} \\
\text { parenterally }\end{array}$} & \multicolumn{3}{|c|}{$\mu \mathrm{g} F \mathrm{Fe} / 100 \mathrm{ml}$ serum } & \\
\hline & & & & & SI & UIBC & TIBC & \\
\hline 33 & $\hat{o}$ & - & - & $\mathrm{X}$ & 45 & destroyed & $d-$ & none \\
\hline 34 & $\hat{o}$ & - & - & $\mathbf{X}$ & 125 & 176 & 301 & none \\
\hline 35 & 운 & - & — & $\mathrm{X}$ & 185 & 246 & 431 & none \\
\hline 36 & $\hat{o}$ & 一 & $\mathbf{x}$ & - & 1056 & 0 & 1056 & $\begin{array}{l}\text { very small and } \\
\text { weak piglet died }\end{array}$ \\
\hline 37 & $\hat{o}$ & - & $\mathbf{X}$ & - & 996 & 90 & 1086 & none \\
\hline 38 & $\hat{o}$ & - & $\mathbf{X}$ & - & 1056 & 0 & 1056 & none \\
\hline 39 & 우 & - & $\mathbf{X}$ & - & 1050 & 0 & 1050 & none \\
\hline 40 & $\hat{o}$ & $\mathbf{x}$ & - & $\mathbf{X}$ & 705 & 43 & 748 & none \\
\hline 41 & q & $\mathbf{X}$ & - & $\mathrm{X}$ & 549 & 0 & 549 & none \\
\hline 42 & $\hat{o}$ & $\mathbf{X}$ & - & $\mathbf{X}$ & no & blood sam & aple & none \\
\hline
\end{tabular}

T a b l e 5. Sex, treatment, serum iron (SI), unsaturated iron-binding capacity (UIBC), total iron-binding capacity (TIBC) and complications of piglets 3 days of age from litter 5 .

\begin{tabular}{|c|c|c|c|c|c|c|c|c|}
\hline \multirow{3}{*}{ Piglet no. } & \multirow{3}{*}{ Sex } & \multicolumn{3}{|c|}{ Blood sample taken } & & & \multirow{2}{*}{ serum } & \multirow{3}{*}{ Complications } \\
\hline & & \multirow{2}{*}{$\begin{array}{c}\text { after } \\
100 \mathrm{mg} \mathrm{Fe} \\
\text { orally }\end{array}$} & \multirow{2}{*}{$\begin{array}{c}\text { after } \\
100+250 \text { mg Fe } \\
\text { oral.+ parent. }\end{array}$} & \multirow{2}{*}{$\begin{array}{c}\text { before } \\
250 \mathrm{mg} \mathrm{Fe} \\
\text { parenterally }\end{array}$} & \multicolumn{2}{|c|}{$\mu \mathrm{g} \mathrm{Fe} / 100 \mathrm{ml}$} & & \\
\hline & & & & & SI & UIBC & TIBC & \\
\hline 43 & 우 & - & - & $\mathrm{X}$ & 85 & 205 & 290 & none \\
\hline 44 & q & - & - & $\mathbf{X}$ & 117 & 180 & 297 & none \\
\hline 45 & $\hat{o}$ & 一 & - & $\mathbf{X}$ & 62 & 361 & 423 & none \\
\hline 46 & 우 & - & - & $\mathbf{X}$ & 87 & 161 & 248 & died \\
\hline 47 & 우 & - & $\mathbf{X}$ & - & 740 & - & 279 & none \\
\hline 48 & $\hat{o}$ & - & $\mathbf{X}$ & 一 & 720 & - & 414 & none \\
\hline 49 & $\hat{o}$ & - & $\mathrm{X}$ & - & 740 & - & 404 & none \\
\hline 50 & 우 & $\mathbf{x}$ & - & $\mathrm{X}$ & 420 & 5 & 425 & none \\
\hline 51 & 우 & $\mathbf{X}$ & - & $\mathbf{X}$ & 345 & 26 & 371 & none \\
\hline 52 & $\hat{\delta}$ & $\mathbf{X}$ & - & $\mathbf{X}$ & 330 & 74 & 404 & none \\
\hline 53 & 운 & $\mathbf{X}$ & - & $\mathbf{X}$ & 381 & 24 & 405 & none \\
\hline
\end{tabular}

iron preparation was given simultaneously with oral iron to 17 piglets from the same litters at the same time, values for iron in serum were obtained which exceeded the iron-binding capacity without any toxic symptoms appearing. For control purposes, 20 other piglets, which did not receive oral iron were 
Table 6. Sex, treatment, serum iron (SI), unsaturated iron-binding capacity (UIBC), total iron-binding capacity (TIBC) and complications of piglets $3 \frac{1}{2}$ days of age from litter 6 .

\begin{tabular}{|c|c|c|c|c|c|c|c|c|}
\hline \multirow{3}{*}{ Piglet no. } & \multirow{3}{*}{ Sex } & \multicolumn{3}{|c|}{ Blood sample taken } & & & & \multirow{3}{*}{ Complications } \\
\hline & & \multirow{2}{*}{$\begin{array}{c}\text { after } \\
100 \mathrm{mg} \mathrm{Fe} \\
\text { orally }\end{array}$} & \multirow{2}{*}{$\begin{array}{c}\text { after } \\
100+250 \mathrm{mg} \mathrm{Fe} \\
\text { oral. + parent. }\end{array}$} & \multirow{2}{*}{$\begin{array}{c}\text { before } \\
250 \mathrm{mg} \mathrm{Fe} \\
\text { parenterally }\end{array}$} & \multicolumn{3}{|c|}{$\mu \mathrm{g} \mathrm{Fe} / 100 \mathrm{ml}$ serum } & \\
\hline & & & & & SI & UIBC & TIBC & \\
\hline 54 & $\hat{o}$ & - & - & $\mathrm{X}$ & 14 & 365 & 379 & none \\
\hline 55 & 웅 & - & - & $\mathbf{X}$ & 17 & 401 & 418 & none \\
\hline 56 & 우요 & - & - & $\mathrm{X}$ & 92 & 363 & 428 & none \\
\hline 57 & $\hat{o}$ & - & $\mathbf{X}$ & - & 992 & - & 527 & none \\
\hline 58 & $\hat{o}$ & - & $\mathbf{X}$ & - & 772 & - & 592 & none \\
\hline 59 & 우요 & - & $\mathbf{X}$ & - & 972 & - & 578 & none \\
\hline 60 & 웅 & - & $\mathbf{X}$ & - & 1040 & - & 675 & died \\
\hline 61 & $\hat{o}$ & $\mathbf{X}$ & - & $\mathbf{X}$ & 630 & - & 534 & none \\
\hline 62 & $\hat{o}$ & $\mathbf{X}$ & - & $\mathbf{X}$ & 621 & - & 606 & none \\
\hline 63 & 우 & $\mathbf{X}$ & - & $\mathbf{X}$ & 450 & 5 & 455 & none \\
\hline 64 & 우 & $\mathbf{X}$ & - & $\mathbf{X}$ & 870 & 19 & 889 & none \\
\hline
\end{tabular}

T a ble 7. Sex, treatment, serum iron (SI), unsaturated iron-binding capacity (UIBC), total iron-binding capacity (TIBC) and complications of piglets 3 days of age from litter 7 .

\begin{tabular}{|c|c|c|c|c|c|c|c|c|}
\hline \multirow{3}{*}{ Piglet no. } & \multirow{3}{*}{ Sex } & \multicolumn{3}{|c|}{ Blood sample taken } & & & & \multirow{3}{*}{ Complications } \\
\hline & & \multirow{2}{*}{$\begin{array}{c}\text { after } \\
100 \mathrm{mg} \mathrm{Fe} \\
\text { orally }\end{array}$} & \multirow{2}{*}{$\begin{array}{c}\text { after } \\
100+250 \mathrm{mg} \mathrm{Fe} \\
\text { oral.+ parent. }\end{array}$} & \multirow{2}{*}{$\begin{array}{c}\text { before } \\
250 \mathrm{mg} \mathrm{Fe} \\
\text { parenterally }\end{array}$} & \multicolumn{3}{|c|}{$\mu \mathrm{g} \mathrm{Fe} / \mathbf{1 0 0} \mathrm{ml}$ serum } & \\
\hline & & & & & SI & UIBC & TIBC & \\
\hline 65 & $\hat{o}$ & - & - & $\mathbf{X}$ & 35 & 444 & 479 & none \\
\hline 66 & $\hat{o}$ & - & - & $\mathbf{X}$ & 78 & 305 & 383 & none \\
\hline 67 & ㅇ & - & - & $\mathbf{X}$ & 48 & 399 & 447 & none \\
\hline 68 & $\hat{o}$ & - & $\mathbf{X}$ & - & 592 & 22 & 614 & none \\
\hline 69 & 운 & - & $\mathbf{X}$ & 一 & 688 & - & 444 & none \\
\hline 70 & $\hat{o}$ & - & $\mathbf{X}$ & - & 648 & - & 581 & none \\
\hline 71 & 우 & $\mathbf{X}$ & - & $\mathbf{X}$ & 396 & 73 & 469 & none \\
\hline 72 & $\hat{o}$ & $\mathbf{X}$ & - & $\mathbf{X}$ & 486 & 18 & 504 & none \\
\hline 73 & \% & $\mathbf{X}$ & - & $\mathbf{X}$ & 510 & 60 & 570 & none \\
\hline 74 & $\hat{o}$ & $\mathbf{X}$ & - & $\mathbf{X}$ & 435 & 87 & 522 & none \\
\hline
\end{tabular}

taken from the same litters and treated with parenteral iron at the same time as the other groups. Neither here did any fatalities occur that could be correlated to the iron treatment. Three piglets (Nos. 36, 46 and 60) died by internal bleeding during the blood sampling. 
Correlation between UIBC, infection and the sudden fatalities

It was observed that the majority of animals that died after treatment with parenteral iron showed signs of intestinal disorder in the form of diarrhoea, and the post-mortem examination of these piglets revealed that in most cases there was an acute enteritis (Brag, Nordblom, personal communication). In order to study whether a correlation exists between UIBC intestinal infections and the sudden fatalities, experiments were carried out on a farm where there had been problems with enteritis of the piglets. It can be seen from Tables 8 and 9 that the ironbinding capacity before administration of parenteral iron was

T a b l e 8. Unsaturated iron-binding capacity (UIBC) and complications of 4-day old piglets with intestinal infections from litter 8.

\begin{tabular}{ccc}
\hline Piglet no. & UIBC & Complications \\
\hline 75 & 425 & none \\
76 & 412 & none \\
77 & 285 & none \\
78 & 525 & none \\
79 & 410 & none \\
80 & 360 & dead 2 days after treatment \\
81 & 380 & none \\
82 & 350 & none \\
83 & 575 & none \\
84 & 425 & none \\
85 & 470 & dead 2 days after treatment \\
\hline
\end{tabular}

T a b l e 9. Unsaturated iron-binding capacity (UIBC) and complications of 2-day old piglets with intestinal infections from litter 9 .

\begin{tabular}{ccc}
\hline Piglet no. & UIBC & Complications \\
\hline 86 & 255 & none \\
87 & 215 & none \\
88 & 175 & none \\
89 & 220 & dead 1 day after treatment \\
90 & 275 & none \\
91 & 200 & dead 1 day after treatment \\
92 & 215 & none \\
93 & 215 & dead 1 day after treatment \\
94 & 200 & none \\
95 & 225 & none \\
96 & 140 & none \\
97 & 100 & none \\
\hline
\end{tabular}


high among these groups of animals in spite of most of the piglets having infection clinically manifested in the form of diarrhoea. The post-mortem examination of the dead piglets revealed nothing which suggests a connection between these fatalities and the treatment with parenteral iron. The cause of death of these piglets (Nos. 80, 85, 89, 91 and 93) has probably connection with an acute catarrhal enteritis. E. coli-infection was found (Shreeve \& Thomlinson 1970).

\section{DISCUSSION}

On treating pregnant women for iron deficiency anaemia with an iron-sorbitol complex for parenteral use, Scott (1962) observed that 3 patients manifested side-effects. These patients had been treated at the same time with oral iron, which resulted in saturation of the transferrin, and iron from the parenteral preparation could not be bound to the transferrin, but gave rise to side-effects. According to Behrens (1969), a causal relationship may exist between the total iron-binding capacity of animals and sudden fatalities. If this were the case, the piglets ought to be particularly sensitive to a large dose of parenteral iron after saturation of the transferrin with oral iron in analogy with Scott's results. However, the results of this investigation show that saturation of the transferrin does not give rise to any fatal side-effects on administering parenteral iron.

According to Behrens, one of the reasons for the fatalities is a specific toxicity of the iron preparation. He also considers that certain litters are especially susceptible, but that vitamin $\mathrm{E}$ deficiency may be ruled out as a cause of the fatalities as well as a specific infection on injection. Köhler (1966) investigated the dead animals with regard to infection and ascertained that fatalities occurred both in litters with a bacterial infection of the piglets as well as in litters where no infection could be established. However, he showed that in most cases there was a slight intestinal catarrh. In the present investigation, no fatalities could be established as a result of treatment with parenteral iron at the farm where intestinal infections had given obvious trouble. This supports the view that the bacterial infection found in certain of the dead piglets had nothing to do with the sudden fatalities. However, this does not rule out that the intestinal infection could have made the animals sensitive to the parenteral iron.

It was shown by Beeson (1947 a) that daily i. v. injections 
of the same dose of bacterial pyrogens led to a decrease in the febrile reaction of the animals. The author considered that development of resistance was not a result of the production of specific humoral antibodies. On blocking the R-E system of such animals with colloidal thorium dioxide, Beeson (1947 b) found that the animals once again became sensitive to the bacterial pyrogens. He also showed that the pyrogenic substances were removed more quickly from the circulating blood of the animals, which were tolerant to pyogens, than from that of normal animals and that blocking the R-E system caused retardation of this quicker elimination.

The various parenteral preparations, which were used at the time of the reported fatalities, have in common a high average molecular weight. The large dose of iron colloid which is administered to the piglets can temporarily block the R-E system of the animals. In animals exposed to toxins from a specific microorganism, which produces a large amount of toxin in the intestinal tract, such a blockade by the iron colloid might in analogy with Beeson's (1947ab) results - be one possibility for increasing to a sufficiently high degree the risk for sudden fatalities to occur.

\section{REFERENCES}

Beeson, P. B.: Tolerance to bacterial pyrogens. I. Factors influencing its development. J. exp. Med. 1947 a, 86, $29-38$.

Beeson, P. B.: Tolerance to bacterial pyrogens. II. Role of the reticulo-endothelial system. J. exp. Med. 1947 b, 86, 39—44.

Behrens, $H$.: Todesfälle bei Saugferkeln nach Injektion von Eisenpräparaten. (Mortality among unweaned piglets following the injection of iron preparations). Die Blauen Hefte 1969, 41, 17-23.

Brag, S.: Profylax och terapi vid järnbristanemi hos spädgrisar. (Prophylaxis and therapy of iron-deficiency anaemia in piglets). Medlemsbl. Sveriges Vet.-förbund 1957, 9, 321-323.

Brag, S.: Personal communication.

Cartwright, G. E. \& M. M. Wintrobe: Chemical, clinical and immunological studies on the products of human plasma fraction XXXIX. The anemia of infection studies on the iron-binding capacity of serum. J. clin. Invest. 1949, 28, 86-98.

Giovanniello, T. J., G. Dibenedetto, D. W. Palmer \& T. Peters, jr.: Fully automated method for the determination of serum iron and total iron-binding capacity. Automation in analytical chemistry, Technicon Symposia 1967, Vol. I, 185-188.

Henriksson, K.: Förgiftning i samband med järnterapi hos gris. (Poisoning of piglets during iron therapy). Finsk Vet.-T. 1962, 68, 293-297. 
Högberg, K.-G., S. Lindvall, K. Orth, B. Thafvelin \& K. Uthne: Studies on a new intramuscular haematinic for piglet anaemia. Acta vet. scand. $1968,9,10-32$.

Köhler, H.: Untersuchungen zur Klärung von Todesfällen bei Schweinen nach Injektionen von Eisenkomplexverbindungen. (The cause of death in pigs injected with iron complexes). Berl. Münch. tierärztl. Wschr. 1966, 79, 337-340, 345-349.

Lannek, N. \& G. Tollerz: Överkänslighet hos E-vitaminfattiga smågrisar mot järnbehandling. (Hypersensitivity to iron injections of piglets deficient in vitamin E). Medlemsbl. Sveriges Vet.förbund 1962, 14, 29-33.

Lindvall, S. \& N. S. E. Andersson: Studies on a new intramuscular haematinic iron-sorbitol. Brit. J. Pharmacol. 1961, 17, 358-371.

Nilsson, $P$. O.: Några fall av akut järnförgiftning med myokardskada hos smågrisar. (Acute iron poisoning with myocardial degeneration in piglets). Nord. Vet.-Med. 1960, 12, 113-119.

Nordblom, B.: Personal communication.

Scott, $S$. M.: Toxicity of iron sorbitol citrate. Brit. med. J. 1962, 2, 480. Shreeve, B. J. \& J.R. Thomlinson: Escherichia Coli disease in the piglet. A pathological and bacteriological investigation. Brit. vet. J. $1970,126,444-451$.

Ueberschär, S.: Todesfälle bei Saugferkeln nach Applikation von Eisen-Dextran Präparaten. (Fatalities among piglets given iron dextran preparations). Dtsch. tierärztl. Wschr. 1966, 73, 145150.

\section{SAMMANFATTNING}

Studier över dödsfall hos spädgrisar i samband med parenteral järnterapi.

En undersökning har utförts med syfte att klarlägga om någon korrelation föreligger mellan den latenta järnbindande kapaciteten, UIBC, i serum hos spädgrisar och plötslig död hos dessa djur, då de behandlas med $250 \mathrm{mg}$ trevärt järn i form av ett komplex även innehållande dextrin, sorbitol, citron- och mjölksyra.

Nittiosju djur fördelade på 9 kullar har använts. Genom att tillföra $100 \mathrm{mg}$ 2-värt järn peroralt till 22 andra djur är den järnbindande kapaciteten mättad eller kraftigt reducerad 3 timmar efter den orala behandlingen. Vid denna tidpunkt har djuren behandlats med parenteralt järn. Sjutton andra djur behandlades med $100 \mathrm{mg}$ 2-värt järn och omedelbart därefter med parenteralt järn. Tre timmar senare har djurens järnbindande kapacitet överskridits. Hos 32 av kontrolldjuren var UIBC hög före den parenterala behandlingen. Några dödsfall observerades ej hos de med parenteralt järn behandlade djuren.

Tjugotre av djuren hade trots diarré en hög järnbindande kapacitet. Vid parenteral behandling av dessa djur med järnkomplexet observerades inga dödsfall som kunde hänföras till behandlingen.

Mekanismen för plötslig död hos spädgrisar efter parenteral järntillförsel har diskuterats.

(Received April 19, 1971).

Reprints may be requested from: Sven Lindvall, Astra Läkemedel AB, S-151 85 Södertälje, Sweden. 